\title{
Paradiplomacy Pemerintah Kota Bandung Melalui Kerja Sama Sister City
}

\author{
Gilang Nur Alam ${ }^{1}$ dan Arfin Sudirman ${ }^{2}$ \\ ${ }^{1}$ Departemen Hubungan Internasional, Universitas Padjadjaran, gnuralam@unpad.ac.id \\ ${ }^{2}$ Departemen Hubungan Internasional, Universitas Padjadjaran, arfin.sudirman@unpad.ac.id
}

\begin{abstract}
ABSTRAK
Berbagai bentuk kerja sama internasional yang telah dilakukan oleh Kota Bandung di antaranya bertujuan untuk mendapatkan penerimaan dana hibah, investasi jangka panjang maupun pendek, bantuan infrastruktur, pertukaran pemuda, beasiswa, dan kerja sama kebudayaan. Kerja sama tersebut merupakan langkah-langkah paradiplomasi Kota Bandung yang dilakukan melalui skema sister city, pembentukan proyek bersama, dan berbagai bentuk pengiriman delegasi yang dilakukan antar aktor sub-nasional. Posisi artikel ini berupaya untuk mengkaji keterlibatan pemerintah kota khususnya kota Bandung dalam melaksanakan hubungan luar negerinya yang kemudian memfokuskan untuk memahami bagaimana konsep sister city yang sudah banyak dilakukan di berbagai negara dapat dilihat melalui pendekatan paradiplomasi di Indonesia. Paradiplomasi Kota Bandung dalam bentuk sister city dengan para mitra kotanya membuahkan beberapa keuntungan dan juga sekaligus peluang demi meningkatkan kesejahteraan masyarakat kota sekaligus berpartisipasi di dalam pembangunan nasional khususnya dalam mengembangkan diplomasi Indonesia. Penelitian ini menggunakan metode kualitatif dengan bersumber pada data yang diperoleh melalui studi lapangan, dan studi literatur.
\end{abstract}

Kata kunci: Paradiplomasi, sister city, kerja sama internasional, aktor sub-nasional

\begin{abstract}
Various forms of international cooperation that have been carried out by the City of Bandung are aimed at obtaining receipt of grant funds, long and short-term investments, infrastructure assistance, youth exchanges, scholarships, and cultural cooperation. The collaboration is a step in the paradiplomation of the City of Bandung, which is carried out through the sister city scheme, the formation of joint projects, and various forms of delegation sending between subnational actors. The position of this article seeks to examine the involvement of the city government, especially the city of Bandung in carrying out its foreign relations which then focuses on understanding how the sister city concept that has been widely practiced in various countries can be seen through paradiplomation approaches in Indonesia. Paradiplomacy of Bandung City in the form of sister city with its city partners produced several benefits and at the same time an opportunity to improve the welfare of urban communities while participating in national development, especially in developing Indonesian diplomacy. This study uses qualitative methods based on data obtained through field studies and literature studies.
\end{abstract}

Keywords: Paradiplomacy, sister city, international cooperation, sub-national actor

\section{Pendahuluan}

Bandung dikenal oleh dunia sebagai suatu kota yang menjadi bagian dari sejarah internasional. Berbagai konferensi besar pernah diadakan di kota ini. Salah satunya adalah Konferensi Asia
Afrika. Konferensi Asia Afrika (KAA) telah dilaksanakan sejak tahun 1955 dan hingga saat ini konferensi tersebut telah diperingati sebanyak 60 kali dengan mengundang berbagai representasi negara lain di Asia dan Afrika, baik kepala negara 
maupun kepala pemerintahan. Konferensi terakhir telah dilakukan di Kota Bandung pada 19-24 April 2016 yang diikuti oleh 77 negara ${ }^{1}$.

Berbagai bentuk kerja sama internasional yang telah dilakukan oleh Kota Bandung di antaranya penerimaan dana hibah, investasi jangka pendek, bantuan infrastruktur, pertukaran pemuda, beasiswa, dan kerja sama kebudayaan. Sedangkan, negara yang menjadi mitra kerja sama Kota Bandung di antaranya kebanyakan adalah negara yang berada di benua Asia, Amerika, maupun Eropa yang meliputi Malaysia, Belanda, Amerika Serikat, Australia, Norwegia, Swedia, Korea Selatan, Jepang, Jerman, Thailand dan Selandia Baru.

Kerja sama yang dilakukan oleh pemerintah Kota Bandung melalui Ridwan Kamil merupakan kerja sama yang berkaitan dengan kepentingan kota Bandung itu sendiri. Upaya-upaya yang dilakukan oleh Pemkot Bandung melalui Ridwan Kamil juga merupakan upaya yang menarik investasi dan juga mengupayakan keuntungan seoptimal mungkin bagi Kota Bandung.

Paradiplomasi secara umum dapat diterjemahkan sebagai suatu aktivitas yang dilakukan oleh entitas sub-nasional atau sub-state dalam melakukan kegiatan diplomasi dengan mitra luar negerinya. Hal ini didasarkan pada pendapat Daniel Bell $^{2}$ yang menyatakan bahwa negara sudah terlalu besar dalam menyelesaikan permasalahan atau mengurusi hal-hal kecil dan di saat yang sama negara terlalu kecil untuk mengurusi hal-hal yang besar. Oleh karena itulah kemudian negara tidak lagi menjadi aktor tunggal melainkan

\footnotetext{
${ }^{1}$ The History of the Asian-African Conference, [online]. Diakses melalui $<$ http://asianafricanmuseum.org/en/sejarahkonferensi-asia-afrika/>

${ }^{2} \mathrm{D}$. Bell, The third technological revolution and its possible socio economic consequences. Dissent, 36 (2), p.167.
}

kemudian aktor-aktor sub-nasional mulai mengambil alih dan turut serta di dalam aktivitas hubungan internasional demi kepentingan masing-masing entitas yang bersangkutan. Selain sebagai wujud otonomi, hubungan internasional yang dilakukan oleh aktor sub-nasional merupakan suatu cara yang lebih mudah guna menyelesaikan berbagai kepentingan daerah alih-alih kepentingan nasional. Karena meski bagaimanapun, hanya aktor sub-nasional itu sendiri yang lebih mengetahui mengenai daerahnya dan potensi yang dimiliki dibandingkan dengan pemerintah pusat.

Bentuk-bentuk paradiplomasi selain terdiri dari pencarian investasi juga terdiri dari sister city, pembentukan proyek bersama, dan berbagai bentuk pengiriman delegasi yang dilakukan antar aktor subnasional ${ }^{3}$. Artikel ini akan lebih berfokus kepada paradiplomasi dalam bentuk sister city yang dilakukan oleh pemerintah Kota Bandung dengan mitra kotanya. Secara spesifik, artikel ini berfokus kepada paradiplomasi dalam bentuk sister city yang dilakukan antara Pemerintah Kota Bandung dengan Kota Braunschweig di Jerman dan Kota Suwon di Korea Selatan.

Posisi artikel ini berupaya untuk mengkaji hubungan luar negeri daerah yang dilakukan oleh pemerintah kota Bandung yang kemudian memfokuskan untuk memahami bagaimana konsep sister city yang sudah banyak dilakukan di berbagai negara dapat dilihat melalui pendekatan paradiplomasi di Indonesia. Hal ini dilakukan untuk mengisi kesenjangan yang ada dalam artikel-artikel terdahulu mengenai sister city dengan

\footnotetext{
3 Miguel Santos Neves, Paradiplomasi, Knowledge Regions and the Consolidation of "Soft Power" Vol 1. e-Journal of International relation e-ISSN 1647-7251

Portugal: Universidade Autónoma de Lisboa,
} 
memberikan penekanan-penekanan sebagai berikut:

a) Secara konseptual artikel ini akan mengkaji konsep sister city dan peran pemerintah kota Bandung dalam arena internasional yang dinaungi oleh UU No. 32 tahun 2004 tentang Pemerintahan Daerah, dan UU No.24 tahun 2000 tentang Perjanjian Internasional telah memberikan keleluasaan bagi pemerintah kota untuk menjalin foreign relation atau hubungan luar negeri dengan mitra dari negara lain.

b) Artikel akan lebih memusatkan pada pemahaman mengenai konsep paradiplomasi dapat dilakukan oleh kota Bandung sebagai pemerintah kota dapat merepresentasikan negara di kancah internasional.

c) Artikel ini juga akan mengkaji kesesuaian konsep paradiplomasi dengan kerangka kerja sama internasional yang dibentuk dalam jalinan sister city.

Berdasarkan paparan tersebut, maka artikel ini berupaya untuk menjelaskan bagaimana paradiplomasi kota Bandung dilakukan melalui skema sister city. Hal ini akan memberikan pemahaman pada proses diplomasi yang dijalankan oleh pemerintah kota dapat mengambil peranan dari sebuah negara dalam mencapai kepentingannya. Atas dasar pemikiranpemikiran di atas dan latar belakang, maka artikel ini memunculkan pertanyaan yang dihimpun ke dalam rumusan masalah "Bagaimana Pemerintah Kota Bandung Melakukan Paradiplomasinya untuk memenuhi kebutuhan Politik, Ekonomi, dan Budaya Melalui Sister city Kota

Bandung dengan Mitra Kotanya?”.

Artikel ini memiliki tujuan untuk memberikan informasi tambahan sekaligus menjelaskan bahwa dalam konteks hubungan internasional, pelaksanaan diplomasi kota khususnya Kota Bandung melalui sister city dapat menjadi modal utama dalam mencapai kepentingan negara secara umum dan kota khususnya. Artikel ini diharapkan mampu untuk mengkritisi konsep dari paradiplomasi yang mungkin dapat menguatkan, mengaplikasikan ataupun menggugurkan teorisasi yang ada dalam paradiplomasi.

\section{Kerangka Teoritis}

Untuk menjelaskan bagaimana kehadiran Sub-State Government atau pemerintah kota yang hadir sebagai agen internasional, maka diperlukan sebuah perspektif lain dalam Hubungan Internasional yang digunakan sebagai upaya dalam menjelaskan variable dari level of analysis fenomena tersebut. Artikel ini melihat melalui perspektif lain yang ada dalam Hubungan Internasional yakni, Paradiplomasi dan Sister city, serta interrelasi antar konsep kunci tersebut dengan melihat artikel-artikel yang pernah dilakukan sebelumnya.

Menurut Rosenau ${ }^{4}$, hubungan antar pemerintah selain negara memiliki pola yang rumit daripada pola yang yang sudah tetap dan tidak lagi ekslusif dimiliki oleh negara dan pemerintahan nasionalnya. Melihat pendapat dari Rosenau tersebut, maka pola yang ada dalam Hubungan Internasional seperti konflik dan kerja sama ini dapat melibatkan aktor-aktor lain seperti Sub State Governments, Non-Governmental Organisations (NGOs), Multi National Corporates dan Rezim International. Dalam artikel ini pola utama yang diamati adalah khusus mengenai keterlibatan aktor substate government.

Melalui perspektif neo-liberal ini, fenomena Sub-State Government yang

\footnotetext{
${ }^{4}$ J.N Rosenau (1997), Along the DomesticForeign Frontier: Exploring Governance in a Turbulant World; dalam Fritz Ikone Nganje; Paradiplomasi: A Comparative Analyuses of the International Relation of South Africa Gauteng, North West and Western Cape Province, 2013
} 
berkembang sebagai agen internasional merupakan sebuah manifestasi dari adanya perubahan struktur dalam sistem internasional. Paradiplomasi kemudian muncul sebagai konsep yang hadir dan dapat dijelaskan sebagai respon oleh Pemerintah Kota dalam menyikapi globalisasi, serta ketidakmampuan negara untuk melindungi entitas di bawahnya dalam menghadapi proses globalisasi tersebut. Hal inilah yang mendorong hadirnya kegiatan-kegiatan diplomasi yang dilakukan oleh Sub State Government sejalan dengan kepentingannya dalam kemajuan ekonomi kotanya.

Dalam kasus pemerintah Kota Bandung misalnya, teridentifikasi bahwa kemajuan ekonomi kota, maka pemerintah kota terlibat dalam aktivitas internasionalnya di bidang ekonomi, hal ini

bisa menghasilkan sebuah peraturan baru dalam aktivitas ekonomi untuk wilayahnya ${ }^{5}$

Konsep paradiplomasi yang saat ini hadir dalam hubungan internasional sebagai perkembangan dari diplomasi modern juga memunculkan persoalan yang menarik untuk diteliti. Mengacu pada pendapat Ivo Duchacek $^{6}$ “...paradiplomacy refers to direct international [activities] by subnational actors (federated units, regions, urban communities, cities...)".

Secara konseptual dan pelaksanaannya, konsep paradiplomasi ini memberikan tantangan bagi disiplin ilmu

5 Hendrini Renola Fitri dan Faisyal Rani, (2009); Implementasi Kerja sama Sister City: Studi Kasus Sister City Bandung- Braunsweigh (2000-2003); Jurnal Transnasional, Vol 5. No1. Juli 2013. Diakses melalui www.ejournal.unri.ac.id/index.php/JTS/article/d ownload/1798/1769

${ }^{6}$ I. Duchacek (1990), Perforated Sovereignties and International Relations: Trans-Sovereign Contacts of Subnational Governments (Eds). dalam Hans J. Michelmann, H.J. \&Soldatos, P. "Federalism and International Relations: The Role of Subnational Units". Oxford: Clarendon Press. p. 25
Hubungan Internasional. Ketika studi Hubungan Internasional tidak mempertimbangkan atau mengenal sub state actor sebagai subjek dari hubungan internasional secara teoritik, sementara dalam konteks praktiknya sub state atau entitas di bawah negara mengklaim bahwa kegiatan hubungan luar negeri merupakan hak, dan sub state memiliki kedaulatan sendiri untuk terlibat di arena internasional. Paradiplomasi dapat dikatakan sebagai kemunculan dari kemampuan aktor selain negara dalam kapasitas mengeluarkan kebijakan luar negeri. Aktor selain negara yang dimaksud adalah pemerintahan kota, pemerintah provinsi, federasi dan satuan unit yang diberikan otonomi khusus oleh negara.

Secara tradisional prinsip-prinsip dasar dari paradiplomasi ini tidak jauh berbeda dengan definisi diplomasi sendiri yang berdasarkan pada tiga prinsip dasar. Pertama, diselenggarakan dalam kerangka menjalin hubungan perdamaian; kedua, saling mengakui terhadap kedaulatan negaranya masing-masing; ketiga, menjalin hubungan persahabatan dalam jangka waktu yang lama ${ }^{7}$.

Sebelum membahas lebih lanjut tentang konsep dari paradiplomasi, adalah sangat penting untuk menentukan definisi kunci dari paradiplomasi itu sendiri. Menurut Rosenau, dalam konteks hubungan internasional telah terjadi "pengembangbiakan" dari aktor-aktor yang memainkan peranannya dalam panggung internasional, dan penambahan aktor dalam hubungan internasional ini lah yang melanggengkan kondisi politik dunia (Rosenau, 1997:67). 7 Rogier van der Pluijm, City Diplomacy: The
Expanding Role of Cities in International
Politics, Netherlands Institute of International
Relations, 2007, Publisher: Netherlands
Institute of International Relations
"Clingendael" 
Perspektif Rosenau yang menjelaskan sekaligus mendukung terhadap kemunculan aktor non negara dalam melakukan kegiatan diplomasi tersebut juga melukiskan kondisi politik dunia saat ini, sekaligus mempengaruhi para penstudi yang mencurahkan perhatiannya pada isu paradiplomasi ini.

Ivo Duchacek $^{8}$

menegaskan bahwa: “...regions can establish permanent offices in foreign capitals or centres of commerce and industry abroad...". Pernyataan tersebut memiliki pengertian bahwa sebenarnya dalam konsep paradiplomasi yang sedang ramai dilakukan oleh negara-negara di Eropa ini, pemerintahan kota atau provinsi dapat mendirikan kantor di pusat kota yang dituju atau di pusat perdagangan dan industri di luar negeri. Hal ini untuk memudahkan pemerintah kota dalam melakukan negosiasi atas kebijakankebijakan yang dikeluarkan oleh negara terkait dengan persoalan yang menyangkut kepentingan kota tersebut.

Menurut Duchacek, konsep paradiplomasi memiliki tipologi yang terbagi ke dalam tiga tipologi dari paradiplomasi yang menjadi konsentrasi dari paradiplomasi yang terbagi ke dalam tiga area geo-politik, yaitu Trans-border Paradiplomacy, Trans-regional Paradiplomasi dan Global Paradiplomacy ${ }^{9}$.

Paradiplomasi trans-regional dikemukakan oleh Duchacek untuk menunjukan hubungan luar negeri yang dilakukan oleh sub state actor ataupun subnasional dengan pemerintahan di luar negaranya yang tidak berbatasan langsung

${ }^{8}$ I. Duchacek (1990), Perforated Sovereignties and International Relations: Trans-Sovereign Contacts of Subnational Governments (Eds). dalam Hans J. Michelmann, H.J. \& P. Soldatos, "Federalism and International Relations: The Role of Subnational Units," Oxford, $\mathrm{p}, 25$

${ }^{9}$ Ibid. atau berdekatan secara geografis. Yang dimaksud dalam hal ini adalah ketika pemerintahan lokal hendak menjalin hubungan luar negerinya dengan pemerintahan di luar negeri maka harus melewati batas (laut) negaranya atau batas wilayah internasional yang sudah ditentukan. Istilah yang tepat untuk menggambarkan situasi ini adalah hubungan luar negeri "leapfrog", kegiatan paradiplomasi ini dilakukan oleh pemerintahan yang berada di wilayah laut Baltik.

Tipologi terakhir yang dikemukakan oleh Duchacek ini, menurut penulis sangat dibutuhkan untuk melihat bagaimana kegiatan paradiplomasi kota Bandung berkaitan dengan kondisi Indonesia yang sudah turut meratifikasi perjanjian perdagangan bebas, seperti AFTA dan ASEAN Community 2015.

Oleh karena itu dalam artikel ini juga turut digolongkan atas tiga layer tersebut dimana penulis membahas mengenai layer ekonomi, politik, dan kerja sama yang juga turut meliputi budaya, teknologi, ilmu pengetahuan, pendidikan dan lain sebagainya.

Sister Cities International ${ }^{10}$, sebuah lembaga yang memberikan perhatiannya pada program kerja sama sister city, menyebutkan bahwa kerja sama sister city sebenarnya memiliki misi yang sudah seharusnya dipahami oleh setiap pemerintah kota di manapun, misinya yaitu "promote peace through mutual respect, understanding and cooperation - one individual, one community at a time". Kegiatan yang terdapat dalam institusi tersebut beberapa kali melibatkan people to people contact melalui program budaya, pendidikan, proyek perdagangan dan lainnya yang dapat memberikan kontribusi terhadap perdamaian.

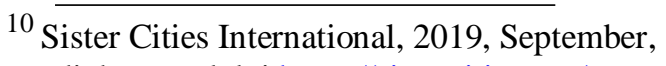
diakses melalui https://sistercities.org/ 
Sister city, atau yang juga dikenal dengan sebutan kota kembar merupakan bentuk dari kerja sama yang disepakati secara resmi dan bersifat jangka panjang di antara dua kota berbeda negara. Tetapi konsep modern tentang sister city menurut dikembangkan dan mendapat dukungan presiden Amerika Serikat, Dwight D. Eisenhower dalam sebuah konferensi nasional yang menawarkan program "people to people" tahun $1956^{11}$. Tujuan dari presiden Eisenhower adalah untuk melibatkan individu dan organisasi masyarakat dari berbagai kalangan dalam pelaksanaan diplomasi, dengan harapan bahwa hubungan antar individu, yang dibangun melalui sister city dapat mengurangi konflik antar negara dimasa akan datang.

Menurut Zelinsky (1990: 25) keinginan untuk mengadakan hubungan antar kota ini muncul dari masyarakat dan pemerintah kota (sub state) dan tidak selalu mengandalkan dukungan dari pemerintah pusat (state $)^{12}$. Melihat keunikan yang terdapat dalam kerja sama sister city, makna atau pemahaman terhadap sister city harus dikarakterisasikan sebagai upaya timbal balik antar kota yang bekerja sama dan bisa mendapatkan keuntungan bersama tanpa harus mengeluarkan dan mengambil keuntungan berlebihan di antara dua kota tersebut.

Karakteristik dari sister city yang terbagi ke dalam tiga struktur sehingga dapat mengidentifikasikan sebuah sister city. Yang pertama adalah Associative, mengarahkan pada gagasan dari "international friendship", pertukaran

\footnotetext{
${ }^{11}$ Hepler. H; "Sister Cities Program Link Culture, Business."American City and Country dalam Ann Dupuis \& Anne De Bruin

Entrepreneurship: New Perspectives in a Global Age, Routledge Revival.

${ }^{12}$ W. Zelinsky, "Sister City Alliance," Journal of American Demographics 12(6)
}

budaya dan kepedulian terhadap isu-isu internasional secara menyeluruh. Selanjutnya Reciproactive, mengembangkan sistem pertukaran di bidang pendidikan. Dan yang terakhir adalah Commercial, upaya mengambil keuntungan dari kedua proses (Associative dan Reciproactive) untuk kepentingan peningkatan ekonomi lokal ${ }^{13}$.

Berdasarkan argumen yang dikemukakan oleh tersebut, terlihat bahwa tujuan akhir dari skema sister city ini adalah bagaimana kemudian dua kota yang bekerja sama ini mampu mengambil keuntungan ekonomi melalui kebudayaan dan pendidikan. Jika merujuk pada argumen tersebut maka pada prinsipnya Pemerintah Kota Bandung memiliki kepedulian untuk meningkatkan jaringan internasionalnya dengan membuka luas international friendship yang bertujuan untuk mengambil keuntungan ekonomi dari kegiatan sister city tersebut.

Walaupun demikian terdapat tiga hal yang menjadi kelemahan dari sister city ini. Pertama, terdapat ketidakpedulian masyarakat atau apatis terhadap hubungan sister city. Kedua, proses pemilihan kota yang akan dijadikan partner tidak melibatkan masyarakat dan cenderung bersifat "strange choice". Ketiga, skema sister city ini sering dijadikan media bagi para politisi untuk melakukan perjalanan ke luar negeri untuk bersenang-senang, dibiayai pemerintah lokal dengan menggunakan sumber dana dari uang pajak yang dibayarkan oleh rakyat ${ }^{14}$.

\footnotetext{
13 Kevin O'Toole (2001), From Mates to Markets: Australian Sister City Type Relationships, journal of Policy, Organisation and Society, 19:1, 43-64, DOI: $10.1080 / 10349952.2000 .11876718$
}

${ }^{14}$ A. Dupuis \& A. de Bruin, International SisterCities: Bridging the Global-Local Divide American Journal of Economics and Sociology 60(1):377-401 DOI: 10.1111/15367150.00066 
Konsep sister city adalah salah satu cara yang sering dilakukan oleh pemerintah kota dalam kegiatan paradiplomasi. Maka, dalam pandangannya yang menjadi objek dari sister city adalah pendidikan, serta aspek politik dengan menekankan kepada kepedulian budaya dan pertukaran budaya. Hal tersebut mengandung makna bahwa sister city merupakan upaya pemerintah di tingkat sub state dalam melakukan hubungan luar negeri.

Dalam artikel ini lingkup kerja sama sister city yang diteliti meliputi seluruh bentuk kerja sama yang dilakukan oleh Pemerintah Kota Bandung dengan pemerintah kota di negara lain, termasuk dalam bidang hubungan/kerja sama yang memerlukan penanganan khusus terutama pada bidang hubungan/kerja sama yang merupakan kewenangan Pemerintah Pusat seperti Kerja sama Teknik Luar Negeri; Kerja sama Ekonomi Sub Regional (KESR); Kerja sama dengan Lembaga Swadaya Masyarakat (LSM) Asing dan sebagainya.

Dalam bentuk praktik di lapangan, kegiatan Pemerintah Kota bandung dalam konteks internasional dilakukan melalui kerangka sister city. Pelaksanaan sister city ini memiliki tujuan menumbuhkan saling pengertian (mutual understanding) melalui pendekatan menyeluruh atau (integrated approach). Dalam hal tersebut, Kota Bandung menjalin hubungan sister city dengan beberapa kota di luar negeri.

Melalui paradiplomasi dalam bentuk sister city ini, terdapat tiga hal yang diteliti, yakni kegiatan paradiplomasi kota bandung dalam bidang ekonomi, sosial budaya, dan politik dengan mitra kotanya yang dijadikan sebagai kota sahabat atau sister city-nya guna mencapai kepentingan dalam meningkatkan kesejahteraan warga kotanya dimana dalam hal ini mitra kota yang menjadi objek adalah Kota Braunscweigh di Jerman dan Kota Suwon di Korea Selatan.

\section{Metodologi}

$\begin{array}{cccr}\text { Riset } & \text { ini } & \text { berupaya untuk } \\ \text { menemukan } & \text { suatu } & \text { pemahaman baru }\end{array}$ mengenai penelusuran fenomena yang dikaji, yakni tentang paradiplomasi di Indonesia dengan studi kasus Pemerintah Kota Bandung. Metode yang digunakan dalam artikel ini yaitu metode kualitatif, karena peneliti tidak berupaya untuk mengukur kuat atau rendahnya hubungan dari suatu fenomena yang terjadi, tetapi didasarkan pada keinginan peneliti untuk mendalami suatu permasalahan tentang bagaimana skema sister city dilakukan sebagai ikhtiar paradiplomasi aktor subnasional.

\section{Upaya Pemerintah Kota Bandung Dalam Memenuhi Kebutuhan Politik, Ekonomi dan Budaya Melalui Paradiplomasi}

Perkembangan interaksi antar
negara saat ini yang telah melibatkan
pemerintahan kota memunculkan
konsekuensi logis dari yakni hadirnya
diplomasi multijalur yang pada
praktiknya menggunakan seluruh
komponen negara di dalam melakukan hubungan kerja sama internasional. Pada tingkat sub state, diplomasi multijalur atau multitrack diplomacy ini diimplementasikan melalui desentralisasi yang diberikan kepada pemerintah kota melalui kewenangan yang telah diberikan oleh pusat. Dengan adanya diplomasi multijalur ini akan dapat menguntungkan aktor sub negara maupun aktor non negara karena dapat melakukan hubungan luar negeri yang saling menguntungkan dengan langsung melalui kontak antar individu (people to people contact). Pada diplomasi dengan menggunakan skema ini, isu yang banyak diangkat adalah isuisu terkait sosial budaya, ekonomi, lingkungan hidup dan sedikit politik. 
Untuk kerja sama sister city yang dilakukan Pemkot Bandung, selain persyaratan yang telah dikemukakan di atas, terdapat beberapa persyaratan lain yang harus dipenuhi oleh Pemkot Bandung, yakni kesetaraan status administrasi; kesamaan karakteristik; kesamaan permasalahan; upaya saling melengkapi; dan peningkatan hubungan antar masyarakat.

Sementara untuk kerja sama yang bersifat teknis, seperti bantuan kemanusiaan, selain persyaratan umum seperti yang telah dikemukakan di atas, maka Pemkot harus pula memperhatikan persyaratan-persyaratan, seperti peningkatan kemampuan dan keterampilan sumber daya manusia dalam penyelenggaraan pemerintahan kota, kemampuan keuangan kota, prioritas produksi dalam negeri dan kemandirian kota.

Paradiplomasi yang dilakukan oleh pemerintah kota memiliki arti penting tidak saja bagi pemerintah kota itu sendiri untuk mengembangkan perekonomian dan kesejahteraan masyarakat di daerahnya, melainkan juga mendukung diplomasi total yang dilakukan oleh pemerintah pusat bagi pencapaian kepentingan nasional Indonesia. Bila dikelola dengan baik, peran pemerintah kota dalam melakukan paradiplomasi akan sangat efektif turut meningkatkan kemampuan diplomasi Indonesia dalam sistem internasional dimana kemudahan untuk melakukan hubungan luar negeri oleh aktor-aktor selain negara menjadi sebuah keniscayaan yang tidak dapat dielakkan dan melalui pengelolaan yang baik terhadap paradiplomasi antara lain melalui penerapan kebijakan yang tepat, akan menghindari terjadi kekhawatiran efek negatif paradiplomasi, seperti mencari dukungan separatis. Begitupun sebaliknya ketika pemerintah Kota tidak mampu memanfaatkan dengan baik hal ini maka akan menyebabkan ketertinggalan kota dari daerah kota lain yang mampu memanfaatkan peluang paradiplomasi yang telah dikelola baik oleh pemerintah pusat.

Kesadaran akan kebutuhan paradiplomasi yang dilakukan oleh pemerintah kota dalam upaya meningkatkan kesejahteraan dan pembangunan ekonomi, serta mempromosikan kebudayaan dan sosial untuk memberdayakan masyarakat di perkotaan menjadikan paradiplomasi sebagai peran yang strategis yang dapat dilakukan oleh birokrasi kota. Oleh sebab itu penguatan kemampuan, kapabilitas dan kapasitas pelaku paradiplomasi di perkotaan mutlak sangat diperlukan. Hanya dengan sumberdaya manusia yang memiliki kemampuan melaksanakan paradiplomasi dengan baik yang dapat menjamin tercapainya tujuan dan manfaat dari pelaksanaan paradiplomasi oleh kota, sehingga tidak terjebak pada kegiatan seremonial belaka.

Salah satu bentuk dari pelaksanaan hubungan luar negeri yang dilakukan oleh Pemerintah Kota Bandung adalah melalui skema kerja sama sister city yang sesuai dengan kajian dari permenlu No: 09/A/KP/XII/2006/01 tentang Panduan Umum Tata Cara Hubungan dan Kerja sama Luar Negeri oleh Pemerintah Daerah dan juga dimasukkan ke dalam UU No. 37 tahun 1999 tentang Hubungan Luar Negeri serta UU No. 32 tahun 2004.

Berdasarkan UU no 32 tahun 2004 tentang pemerintah daerah yang didasarkan kepada semangat desentralisasi dan otonomi daerah, aktor sub state seperti kota dan atau kabupaten dapat berperan secara mandiri untuk melakukan kerja sama internasional dengan pihak lain di luar negeri selama tidak berseberangan dengan kepentingan nasional Indonesia. Dalam hal ini, peran kementerian luar negeri lebih bersifat sebagai fasilitator dan leading 
sector pada praktiknya. Dengan aktifnya pemerintah kota sebagai aktor maka akan dapat mempercepat terjadinya diplomasi total dalam mencapai tujuan yang diinginkan dengan mengoptimalkan seluruh jalur diplomasi yang ada. Terdapat beberapa syarat yang harus dipenuhi oleh pemerintah kota dalam upaya melakukan kerja sama internasional. Syarat-syarat tersebut di antaranya adalah:

1. Hanya dapat melakukan kerja sama dengan negara yang memiliki hubungan diplomatik dengan Indonesia dan dalam kerangka NKRI;

2. Sesuai dengan bidang kewenangan Pemerintah daerah sebagaimana diatur dalam peraturan perundang-undangan nasional Republik Indonesia;

3. Mendapat persetujuan dari Dewan Perwakilan Rakyat Daerah (DPRD);

4. Tidak mengganggu stabilitas politik dan keamanan dalam negeri;

5. Tidak mengarah pada campur tangan urusan dalam negeri masing-masing negara;

6. Berdasarkan asas persamaan hak dan tidak saling memaksakan kehendak;

7. Memperhatikan prinsip persamaan kedudukan, memberikan manfaat dan saling menguntungkan bagi pemerintah daerah dan masyarakat;

8. Mendukung penyelenggaraan pemerintahan, pembangunan nasional dan daerah serta pemberdayaan masyarakat.

Dalam aturan tersebut juga, terdapat syarat dimana pemerintah kota Bandung harus melaksanakan kerja sama internasional secara aman dari berbagai aspek yaitu aspek politis dimana dalam pelaksanaan hubungan luar negeri Pemerintah Kota Bandung tidak bertentangan dengan Politik Luar Negeri dan kebijakan Hubungan Luar Negeri Pemerintah Pusat pada umumnya. Kemudian aspek keamanan dimana kerja sama internasional yang dilakukan oleh Pemerintah Kota Bandung tidak digunakan atau disalahgunakan sebagai akses atau kedok bagi kegiatan asing (spionase) yang dapat mengganggu atau mengancam stabilitas dan keamanan dalam negeri. Aspek Yuridis dimana dalam pelaksanaan kerja sama internasional, terdapat jaminan kepastian hukum yang secara maksimal dapat menutup celah-celah yang merugikan bagi pencapaian tujuan kerja sama serta aspek teknis yang berarti kerja sama tersebut tidak bertentangan dengan kebijakan yang ditetapkan oleh departemen teknis yang terkait.

Terkait dengan multitrack diplomacy dan diplomasi total Indonesia, apa yang dilakukan oleh Pemerintah Kota Bandung sebetulnya menunjang aktivitas diplomasi luar negeri yang dilakukan oleh Kemenlu. Kerja sama lintas sektoral inilah yang kemudian membuat diplomasi multitrack atau diplomasi total Indonesia lebih membumi dengan adanya kontribusi Pemerintah Kota yang menyentuh langsung kepentingan masyarakat di tingkat akar rumput.

Aktor-aktor ekonomi lokal yang sulit dijangkau oleh pemerintah pusat karena faktor geografis dan kendala teknologi informasi dengan mudahnya dapat dijangkau oleh Pemerintah Kota. Tugas pemerintah daerah kemudian mempromosikan potensi ekonomi lokalnya dengan melakukan kerja sama ke luar negeri sehingga dapat menambah PDRB setempat yang dapat digunakan untuk kesejahteraan masyarakat dan pembangunan daerah.

Jika kita memaknai peran Pemerintah Kota dalam melaksanakan kerja sama dengan luar negeri, maka dapat diketahui bahwa peran tersebut memang memiliki batas-batas yang tidak boleh dilewati yang telah diatur oleh Kementerian Luar Negeri. Namun demikian, selain pedoman umum kota dalam melakukan kerja sama luar negeri yang telah ditentukan 
oleh Kementerian Luar Negeri, Kementerian Dalam Negeri pun memiliki aturan terkait dengan aktivitas pemerintah kota jika ingin melakukan kerja sama luar negeri. Aturan tersebut tertuang di dalam Peraturan Menteri Dalam Negeri No. 3 Tahun 2008 tentang Pedoman Pelaksanaan Kerja sama Pemerintah Daerah dengan Pihak Luar Negeri.

Dalam kerja sama antara Kota Bandung dengan luar negeri, tampaknya Pemerintah Kota Bandung masih terlalu terfokus pada $G$ to $G$ cooperation dan tidak memanfaatkan peluang kerja sama dengan organisasi internasional, regional, organisasi non pemerintah dan perusahaan swasta. Hal ini tentu sangat disayangkan mengingat ke seluruh aktor tersebut sangat tertarik untuk melakukan kerja sama dengan Pemkot Bandung. Hal ini pun menjadi ironis manakala Indonesia sudah mencanangkan ASEAN sebagai lingkaran konsentris pertama dalam kebijakan luar negeri RI tetapi belum dimanfaatkan secara optimal oleh Pemerintah Kota Bandung. Selama ini, kerja sama yang dilakukan hanya melibatkan aktor negara saja dan tidak melibatkan aktor-aktor yang lain. Padahal, peluangnya sangat besar jika dilakukan dengan negara-negara anggota ASEAN.

Negara-negara ASEAN menyadari perlunya meningkatkan solidaritas, kohesivitas dan efektivitas kerja sama. Kerja sama antarnegara ASEAN ini pun tidak hanya melibatkan pemerintah pusat tetapi juga pemerintah Kota sebagai unit politik yang paling dekat dengan masyarakat di tingkat akar rumput. Kegiatan kerja sama dalam ASEAN tidak lagi hanya terfokus pada kerja sama ekonomi namun juga harus didukung oleh kerja sama lainnya di bidang keamanan dan sosial budaya. Untuk menjaga keseimbangan itu, pembentukan Komunitas ASEAN 2015 berlandaskan pada 3 (tiga) pilar, yaitu Komunitas Keamanan ASEAN
(ASEAN Security Community), Komunitas Ekonomi ASEAN (ASEAN Economic Community), dan Komunitas Sosial Budaya ASEAN (ASEAN Socio-Cultural Community).

Terdapat tiga kepentingan khusus dibalik kerja sama paradiplomasi yang dilakukan oleh aktor non-negara, dalam hal ini Kota Bandung, yaitu kepentingan ekonomi, sosial budaya, dan juga politik yang kemudian dapat berkontribusi pada pemenuhan kepentingan nasional. Kepentingan-kepentingan tersebut sejauh ini telah dapat terselenggara dengan baik yang dibuktikan dalam program-program yang telah dilakukan oleh Pemerintah kota Bandung baik dengan pemerintah Kota Braunschweig maupun dengan Pemerintah kota Suwon.

Peran komunitas menjadi hal yang penting dan utama di dalam pelaksanaan paradiplomasi yang terjadi antara Kota Bandung dengan mitra kotanya. Hal ini merupakan bukti perkembangan bahwasanya diplomasi dewasa ini tidak hanya dilakukan oleh aktor negara saja namun juga mampu untuk dilakukan pada tingkat sub-nasional khususnya lagi dalam tingkat antar kota. Isu yang dibicarakan dan kerja sama yang dilakukan pun tidak lagi bersifat high politic melainkan menjadi isuisu low politics yang dapat membantu pemerintah pusat menjadi alat lobby kepentingan nasional yang tidak dapat diselesaikan melalui dialog pada tataran pemerintah pusat.

Paradiplomasi dalam bentuk sister city yang dilakukan oleh pemerintah Kota Bandung kemudian membentuk berbagai upaya-upaya pemenuhan kebutuhan kota Bandung dalam berbagai sektor yakni ekonomi, budaya dan politik. Dalam sektor ekonomi kerja sama yang dilakukan oleh pemerintah Kota Bandung dengan mitra kotanya bertujuan untuk menarik minat investor asing, mempercepat pembangunan ekonomi di dalam kota, mengajak 
perusahaan tersebut untuk melakukan bisnis di kota mitranya, dan sebagai peluang baru pemasaran kebutuhan ekspor. Mengingat tujuan-tujuan tersebut yang berusaha dicapai, maka mitra kota kerja sama sister city dengan Kota Bandung dapat dikatakan sangat bermanfaat secara ekonomi bagi masyarakat maupun bagi kota itu sendiri.

Pada sektor budaya, kerja sama sister city yang dilakukan oleh Kota Bandung membuat Kota Bandung dapat tampil di dalam arena internasional. Hal ini akan mendorong terciptanya kesejahteraan melalui kerja sama budaya, pendidikan, teknologi, dan sebagainya. Sebagai hasilnya, kerja sama ini menghasilkan output berupa pertukaran ide, gagasan, kemajuan teknologi, yang pada akhirnya dapat digunakan untuk kepentingan industri dan ilmu pengetahuan.

Pada sektor politik, image building atau penguatan citra kota, Bandung dapat semakin membangun komunikasi dan relasi dengan mitra kota lainnya dan membuka kesempatan untuk datangnya kerja sama yang lebih intens, serta networking yang lebih luas. Citra negara juga akan makin dimunculkan pada tataran internasional sehingga kontribusi negara di dunia internasional akan semakin meluas. Hal ini juga akan membantu mengurangi konflik di masa depan baik antara kota mitra yang bekerja sama maupun antara negara yang menaunginya karena melibatkan individu dan komunitas masyarakat.

Dari berbagai paparan yang telah dikemukakan, maka program-program paradiplomasi melalui sister city yang dilakukan oleh pemerintah kota Bandung dapat dikategorikan ke dalam kategorikategori berikut.

1. Community/outreach program, program ini dibutuhkan untuk mendirikan fasilitas yang dapat dirasakan manfaatnya bagi warga kota. Dalam kerja sama antara Bandung dan mitra kotanya baik Braunschweig maupun Suwon, program ini dapat dilihat pada pembangunan fasilitasfasilitas dan kerja sama dalam bidang bantuan misalnya dapat diamati pada bantuan infrasruktur dan bakti sosial yang dilakukan oleh delegasi Suwon.

2. Education program, yaitu program yang dilaksanakan secara komprehensif ditujukan bagi warga kota yang ingin melakukan studi di kota yang menjadi mitra kota. Program ini dapat dilihat dari kerja sama pendidikan yang terjadi antara universitas di Bandung dan universitas di Braunschweig maupun Suwon. Juga dapat dilihat melalui pertukaran para peneliti, mahasiswa serta kerja sama artikel antara dua kota.

3. Junior Ranger program yaitu merupakan program yang menyertakan para pemuda dalam kegiatan kepemudaan. Kegiatan pertukaran pemuda ini dapat dilihat dari pertukaran pemuda Bandung dan Suwon dimana masing-masing pemuda saling mempelajari kebudayaan di kota mitranya satu sama lain.

4. Performing Arts program, merupakan program yang menawarkan kesempatan bagi para pelajar untuk melakukan eksplorasi budaya. Hal ini dapat diamati pada program Pameran Kebudayaan seperti yang terjadi pada Suwon Food Festival 2010 dan 2011 serta Hwaseong Cultural Festival 2013 dimana para juru masak Kota Bandung menunjukkan keahlian mereka di Kota Suwon.

5. Special event yakni merupakan kegiatan yang diselenggarakan untuk merayakan hari tertentu dengan melibatkan masyarakat. Hal ini dapat dilihat dari kegiatan yang diadakan pada hari-hari tertentu misalnya tampilnya komunitas Hansamo pada peringatan KAA 2015 lalu. 


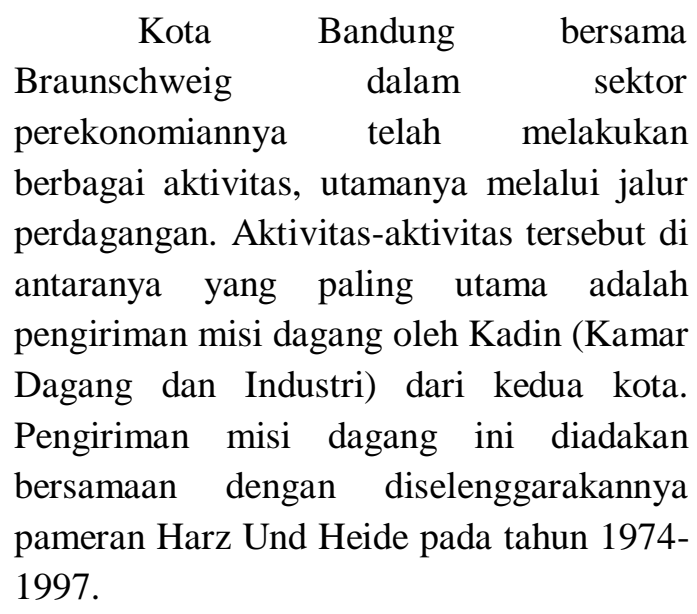

Selain melakukan pengiriman misi dagang, kerja sama ekonomi yang dilakukan juga meliputi penyelenggaraan pasar usaha kecil. Pasar usaha kecil ini diadakan dengan melalui kerja sama antara dua pihak dari kedua kota baik Bandung maupun Braunschweig. Dari pihak Kota Bandung, kerja sama ini dilakukan melalui Dinas Koperasi Kota Bandung sedangkan bagi Kota Braunschweig dilakukan oleh Dinas Koperasi Kota Braunschweig. Kegiatan- kegiatan yang dilakukan di antaranya meliputi Pameran/Promosi Produk dari masing-masing kota, desain produk, pelatihan Pengusaha dan Pejabat Kota Bandung, Kerja sama Simpan Pinjam keuangan, serta Pembentukan Lembaga Bantuan Keuangan.

Hal tersebut membuktikan adanya suatu ketimpangan dari kerja sama sister city yang terjadi dimana suatu kota yang maju secara ekonomi akan menjadi contoh (role model) bagi mitra kota kembarnya dan menjadi pelopor dalam membentuk mitra kotanya hingga menjadi relatif sama dengan kota yang diteladani. Dalam kasus ini kota Braunschweig menjadi model bagi kota Bandung sehingga kemudian proporsi Bandung untuk belajar dari kota Braunschweig lebih besar ketimbang sebaliknya.

Berdasarkan hasil artikel yang telah dilakukan, aspek politik yang terjadi antara Bandung dengan Braunschweig tidak begitu kentara terjadi. Sebab mayoritas aktivitas kerja sama yang terjadi adalah pada aspek sosial budaya dan ekonomi. Hal ini terjadi karena pada dasarnya kerja sama paradiplomasi dalam bentuk sister city tidak melibatkan kegiatan politik. Meskipun secara hard politic aspek politik tidak dapat ditemukan, namun dalam tataran soft politic kerja sama sister city antara Bandung dan Brauncshweig ini memiliki beberapa manfaat bagi kedua kota baik bagi masing-masing kota maupun bagi kedua kota secara integratif. Bagi Kota Bandung, kerja sama kedua kota ini dapat membantu diplomasi Indonesia kepada Jerman. Hal ini dapat dilihat dari bukti bahwa kerja sama yang dilakukan antara aktor sub-nasional dapat lebih efektif dalam meredam konflik, dan memperbaiki hubungan yang kurang baik antara kedua negara $^{15}$.

Dalam aspek sosial budaya, paradiplomasi yang dilakukan mencakup berbagai kegiatan dan berbagai sektor seperti sektor pendidikan, kesenian dan kebudayaan, telekomunikasi dan informatika, pariwisata, kesehatan, serta pemuda dan olahraga.

Salah satu contoh kerja sama di bidang pendidikan antara Kota Bandung dan Braunschweig adalah melalui kerja sama perguruan tinggi yang terjalin antara Padagogische Hochschule yang berada di Braunschweig dan Universitas Pendidikan Indonesia. Universitas lain yang melakukan kerja sama di bidang ini antara lain adalah Institut Teknologi Bandung (ITB) yakni antara Program Studi Dosen dan Mahasiswa Fakultas Seni Rupa ITB dengan HBK pada tahun 1975-2000.

Dalam bidang kesenian dan kebudayaan, aktivitas yang dilakukan meliputi penampilan tim kesenian Kota Bandung pada pameran Harz Und Heide

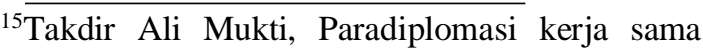
Luar Negeri Oleh Pemda di Indonesia, The Phinisi Press. Yogyakarta, 2013.
} 
dari tahun 1974-1997 juga pada penampilan tim kesenian Kota Bandung pada Event Expo di Hannover dan Braunschweig pada tahun 2000. Pada bidang telekomunikasi dan informatika, kerja sama yang terjadi adalah melalui program pelatihan redaktur radio Lehrgang pada tahun 1972 dan juga pada program pelatihan percetakan/Grafika tahun 1975 yang diberikan oleh Braunschweig kepada Pemerintah Kota Bandung. Selain itu masih banyak lagi program yang merupakan hasil kolaborasi antara Pemerintah Kota Bandung dengan Pemerintah Kota Braunschweig seperti:

1. Program peningkatan siaran radio dan tv.

2. Program pengembangan SDM.

3. Program kesehatan masyarakat.

4. Program pembinaan generasi muda.

5. Program pelatihan pegawai Pemerintah Kota Bandung dalam bidang informatika.

6. Program peningkatan kualitas taman kota.

7. Program peningkatan kualitas aparat kepolisian, tentara, pengadilan, dan kejaksaan.

Program-program

yang

dilaksanakan hingga saat ini merupakan hasil dari Komitmen antara Wali Kota Braunschweig dan Wali Kota Bandung untuk membantu perealisasian programprogram yang telah disepakati antara kedua kota secara berkelanjutan demi tercapainya pembangunan khususnya di Kota Bandung dalam bidang-bidang yang lebih luas lagi seperti bidang budaya, bidang pendidikan dan pelatihan, bidang pertukaran pemuda dan olahraga, program ekonomi perdagangan, serta penataan kota.
Untuk dapat menjalankan programprogram yang telah direncanakan tersebut dan menuju kepada kerja sama yang langsung dapat dilaksanakan oleh masyarakat, maka diperlukan dukungan dari berbagai komponen masyarakat guna mencapai tujuan yang diharapkan. Dalam hal ini, Pemerintah Kota Bandung berperan sebagai koordinator sedangkan masyarakat sebagai pendukung dan turut berperan aktif dalam melaksanakan program yang lebih baik lagi.

Pada satu sisi, Bandung memperoleh banyak bantuan dan pelatihanpelatihan yang diberikan oleh pemerintah Kota Braunschweig, namun di sisi lain kota Braunschweig pun diuntungkan dengan adanya sister city ini sebab kota Braunschweig dapat mencoba untuk memperkenalkan kepada dunia internasional mengenai apa yang mereka miliki, bagaimana cara mereka bekerja, dan bagaimana menjalin persahabatan yang lebih luas lagi dengan berbagai kota mitra yang lain. Oleh karena itu, dapat dikatakan bahwa kerja sama sister city yang lebih mendalam ini dapat menguntungkan kedua belah pihak, baik Bandung maupun Braunschweig meskipun kadar keuntungan yang diperoleh mungkin berbeda.

Kegiatan sister city BandungBraunschweig diketahui telah dimulai sejak 24 Mei 1960 dengan tahapan-tahapan kronologis sebagai berikut. Hal ini diperoleh dari hasil wawancara dengan Ms. Gerlach Elke dari kota Braunschweig (2016) yang dilakukan melalui korespondensi surat elektronik (e-mail).

Tabel 1. Kronologi Hubungan Kerja sama Bandung-Braunschweig

\begin{tabular}{|c|c|l|}
\hline Tahun & Bulan & \multicolumn{1}{c|}{ Kegiatan yang dilakukan } \\
\hline 1960 & Mei & $\begin{array}{l}\text { Penandatanganan kesepakatan (MoU) sister city antara } \\
\text { Bandung-Braunschweig, tepatnya pada 24 Mei 1960 }\end{array}$ \\
\hline
\end{tabular}


44 Gilang Nur Alam \& Arfin Sudirman | Paradiplomasi Pemerintah Kota Bandung Melalui Kerja sama Sister City

\begin{tabular}{|c|c|c|}
\hline $1964-1986$ & - & $\begin{array}{l}\text { Indonesian Cultural Week (Pekan Budaya Indonesia) (setiap 2- } \\
4 \text { tahun sekali) }\end{array}$ \\
\hline $1965-1985$ & - & $\begin{array}{l}\text { Program Pertukaran Magang ( } 1 \text { tahun untuk setiap satu orang } \\
\text { Pegawai Negeri Sipil Kota Bandung untuk mempelajari tata } \\
\text { administrasi) }\end{array}$ \\
\hline 1985 & - & Pertukaran Pemuda mulai dilaksanakan pada tahun ini \\
\hline \multirow{2}{*}{1987} & - & Program Magang PNS Kota Bandung selama 3 bulan \\
\hline & Agustus & Pameran Indonesia di sebuah bank di Braunschweig \\
\hline \multirow{2}{*}{1988} & & Program Magang PNS Kota Bandung selama 3 bulan \\
\hline & Mei & Pekan Kebudayaan Jerman-Indonesia ke-12 di Braunschweig \\
\hline 1989 & Juni/Juli & Program Magang selama 1 bulan untuk PNS Kota Bandung \\
\hline \multirow{3}{*}{1990} & - & Program Magang selama 1 bulan untuk PNS Kota Bandung \\
\hline & April & $\begin{array}{l}\text { Kedatangan Delegasi Resmi Braunschweig di Bandung } \\
\text { (Perayaan } 30 \text { Tahun Kerja sama) }\end{array}$ \\
\hline & - & $\begin{array}{l}\text { Kelompok Senam asal Kota Bandung mengunjungi } \\
\text { Braunschweig }\end{array}$ \\
\hline \multirow[t]{2}{*}{1991} & September & $\begin{array}{l}\text { Delegasi resmi dari Pemerintah Kota bandung mengunjungi } \\
\text { Braunschweig }\end{array}$ \\
\hline & Juni & Program Magang selama 1 bulan untuk PNS Kota Bandung \\
\hline 1992 & & Program Magang selama 1 bulan untuk PNS Kota Bandung \\
\hline \multirow{4}{*}{1993} & \multirow[t]{2}{*}{ April } & $\begin{array}{l}\text { Delegasi Resmi Kota Bandung mengunjungi } \\
\text { Braunschweig }\end{array}$ \\
\hline & & Kunjungan resmi Wali Kota Braunschweig ke Kota Bandung \\
\hline & \multirow{2}{*}{ Mei } & Kota Bandung ikut serta dalam pameran the Harz \& Heide Fair \\
\hline & & Program Magang selama 1 bulan untuk PNS Kota Bandung \\
\hline \multirow[b]{2}{*}{1994} & - & Program Magang selama 1 bulan untuk PNS Kota Bandung \\
\hline & Mei & $\begin{array}{l}\text { Kunjungan resmi dari Universitas Padjadjaran ke } \\
\text { Braunschweig }\end{array}$ \\
\hline \multirow{3}{*}{1995} & \multirow{3}{*}{ Mei } & Kunjungan delegasi resmi dari Bandung ke Braunschweig \\
\hline & & $\begin{array}{l}\text { Perayaan Hari Persahabatan Jerman-Indonesia di } \\
\text { Braunschweig }\end{array}$ \\
\hline & & Program Magang selama 1 bulan untuk PNS Kota Bandung \\
\hline \multirow{3}{*}{1996} & - & Program Magang selama 1 bulan untuk PNS Kota Bandung \\
\hline & Maret/April & $\begin{array}{l}\text { Kunjungan delegasi resmi dari Kota Braunschweig ke } \\
\text { Bandung }\end{array}$ \\
\hline & Juli & Kunjungan delegasi kota Bandung ke Braunschweig \\
\hline 1998 & - & Program Magang selama 1 bulan untuk PNS Kota Bandung \\
\hline 1999 & Maret & $\begin{array}{l}\text { Delegasi Administrasi Kota Braunschweig berkunjung ke } \\
\text { Bandung dalam rangka program water project }\end{array}$ \\
\hline \multirow[t]{2}{*}{2000} & Juli/Agustus & $\begin{array}{l}\text { Perayaan hari jadi kemitraan Braunschweig-Bandung yang ke } \\
40 \text { dan pengiriman kelompok tari selama EXPO } 2000 \text { di } \\
\text { Hannover }\end{array}$ \\
\hline & September & Kunjungan delegasi resmi Braunschweig ke Bandung \\
\hline 2001 & - & Program Magang selama 1 bulan untuk PNS Kota Bandung \\
\hline 2002 & - & Kelompok tari dari Bandung mengunjungi Braunschweig \\
\hline
\end{tabular}


45 Gilang Nur Alam \& Arfin Sudirman | Paradiplomasi Pemerintah Kota Bandung Melalui Kerja sama Sister City

\begin{tabular}{|c|c|c|}
\hline 2003 & - & $\begin{array}{l}\text { Perwakilan representatif kota Bandung untuk sister city } \\
\text { mengunjungi kota Braunschweig untuk mendiskusikan cara- } \\
\text { cara baru dalam berkomunikasi }\end{array}$ \\
\hline 2004 & - & Perayaan ke 40 tahun hari jadi Masyarakat Jerman-Indonesia \\
\hline 2005 & - & $\begin{array}{l}\text { Braunschweig memberikan bantuan dana kepada korban } \\
\text { bencana tsunami }\end{array}$ \\
\hline \multirow[b]{2}{*}{2006} & - & $\begin{array}{l}\text { Bantuan donasi korban tsunami serta pengadaan proyek peduli } \\
\text { yatim di Sumatera }\end{array}$ \\
\hline & Juni & $\begin{array}{l}\text { Delegasi dari Bandung mengunjungi BRaunschweig untuk } \\
\text { belajar tentang proses-proses administrasi dalam sektor } \\
\text { pembangunan, belajar tentang penanganan kebakaran, dan } \\
\text { administrasi publik }\end{array}$ \\
\hline \multirow[t]{2}{*}{2007} & September & $\begin{array}{l}\text { Kunjungan delegasi administrasi Kota Bandung ke } \\
\text { Braunschweig }\end{array}$ \\
\hline & April & Kunjungan delegasi Braunschweig ke Bandung \\
\hline \multirow[t]{2}{*}{2010} & September & $\begin{array}{l}\text { Delegasi resmi dari Braunschweig mengunjungi Bandung } \\
\text { dalam rangka ulang tahun kota }\end{array}$ \\
\hline & Juni & $\begin{array}{l}\text { Perayaan } 50 \text { tahun kemitraan yang diwarnai kunjungan } \\
\text { delegasi Bandung ke Braunschweig }\end{array}$ \\
\hline 2014 & Mei & $\begin{array}{l}\text { Delegasi resmi Bandung mengunjungi Braunschweig untuk } \\
\text { menghadiri hari jadi ke } 50 \text { masyarakat Jerman-Indonesia }\end{array}$ \\
\hline 2016 & Februari & Delegasi resmi Braunschweig berkunjung ke Bandung \\
\hline
\end{tabular}

Kronologi tersebut menandakan bahwa kerja sama yang terjadi antara Pemerintah Kota Bandung dengan pemerintah Kota Braunschweig sudah terjalin sejak lama. Dimulai dari 1960an hingga saat ini. Selama periode tersebut, kegiatan yang mendominasi hubungan paradiplomasi dalam bentuk sister city antara kedua kota adalah kunjungan resmi antara kedua kota, pertukaran budaya, dan pelatihan PNS kota Bandung di Braunschweig. Hal ini membuktikan bahwa Kota Braunschweig memiliki kelebihan dalam bidang tata kelola administrasi sehingga PNS Kota Bandung dapat belajar lebih lanjut tentang hal tersebut di Kota Braunschweig, Hal ini merupakan salah satu keuntungan dari sister city yang dilakukan antara Pemkot Bandung dengan Pemkot Braunschweig.
Aktivitas Ekonomi yang dilakukan antara Bandung dengan Suwon telah terjadi sejak produk hukum berupa Memorandum of Understanding (MoU) antara kedua kota ditandatangani pada tanggal 25 Agustus 1997.

Penandatanganan ini sekaligus menandai terjadinya berbagai kegiatan kerja sama dalam berbagai bidang utamanya dalam bidang perdagangan, investasi, bisnis dan industri.

Dalam bidang perdagangan, aktivitas yang telah dilakukan oleh kedua kota ini di antaranya adalah terjadinya pembicaraan antara Delegasi Bisnis Kota Suwon dengan KADIN Kota Bandung dimana kemudian menghasilkan penghimpunan informasi tentang kegiatan bisnis dan ekonomi di Kota Bandung yang diberikan oleh para pengusaha yang ada di Kota Bandung. 
Kota Bandung dan Kota Suwon di dalam bidang politik telah melakukan beberapa kali kunjungan kerja. Kunjungan kerja yang terjadi seperti pada kunjungan Wali Kota Suwon ke Kota Bandung untuk menghadiri perayaan hari jadi Kota Bandung ke-200 pada tahun 2010. Selain pada tahun 2010, Pemerintah Kota Suwon juga kembali mengunjungi Bandung pada tahun 2011.

Dari hasil pengamatan yang dilakukan, dengan menimbang dari berbagai dokumen, literatur, sumber dan data yang tersedia, maka kunjungan kerja di antara kedua kota kembar/mitra kota dapat peneliti katakan sebagai suatu upaya paradiplomasi dalam aspek politik. Tentunya mengingat terbatasnya wewenang dan ruang lingkup dari kerja sama yang dilakukan, maka kerja sama politik tingkat tinggi (high politic) tidak dapat dilakukan. Namun sebaliknya, kerja sama yang bersifat low politic masih diperbolehkan selama tidak melanggar aturan yang ditentukan oleh Kementerian Luar Negeri Republik Indonesia mengenai kerja sama kota kembar. Kerja sama sister city antara Kota Bandung dengan Suwon dilakukan setelah MoU kerja sama sister city ditandatangani. Hubungan kerja sama tersebut telah terjadi dalam berbagai bidang, di antaranya:

1. Perdagangan

2. Pemuda dan Olahraga

3. Pariwisata

4. Pendidikan

5. Kebudayaan

Kegiatan sister city BandungSuwon menghasilkan inti-inti pokok sebagai berikut. Yang pertama yakni bahwa masyarakat kota Suwon menyukai tarian tradisional dari Bandung yang ditampilkan pada kegiatan kebudayaan Suwon. Hal ini kemudian menjadi salah satu penguat atas hubungan sister city yang dilakukan. Suwon Center for
International Cooperation (SWCIC) menjadi salah satu organisasi yang dibentuk dari prakarsa masyarakat Suwon untuk menjadi pusat bagi hubungan kebudayaan antara Suwon dengan kota lain dalam hal ini Bandung secara khusus. SWCIC bukanlah merupakan organisasi bentukan pemerintah kota Suwon, namun SWCIC mendapatkan kucuran dana dari pemerintah kota Suwon.

Permasalahan utama yang terjadi di dalam kerja sama sister city antara kota Bandung dan kota Suwon adalah adanya hambatan komunikasi, perbedaan waktu, dan biaya komunikasi. Hal ini dapat dimungkinkan dari hambatan atas penggunaan bahasa yang digunakan dalam proses kerja sama, kebutuhan akan penerjemah, dan perbedaan penafsiran yang mungkin terjadi di antara para pengambil kebijakan di masing-masing kota. Secara umum pada saat ini, kerja sama antara kedua kota difokuskan pada aspek kebudayaan dibandingkan aspek kerja sama ekonomi.

Proses pembentukan kerja sama sister city di Indonesia dapat dilakukan secara top down atau bottom up. Pola top down yang dimaksud adalah bahwa usulan kerja sama sister city dikemukakan atau digagas oleh Pemerintah Daerah itu sendiri, pemerintah kota dari negara lain (asing) kepada Pemerintah Daerah (kota/ kabupaten di Indonesia), atau pemerintah kota dari negara lain (asing) langsung melalui Menteri Dalam Negeri yang kemudian permohonan tersebut disampaikan kepada Pemerintah Daerah. Untuk melaksanakan atau mengabulkan permintaan tersebut maka Kepala Daerah menyampaikan usulan kerja sama tersebut kepada DPRD sekaligus meminta persetujuan atas permintaan tersebut.

Berdasarkan hasil wawancara yang dilakukan terhadap Dian T Djani, Dirjen 
47 Gilang Nur Alam \& Arfin Sudirman | Paradiplomasi Pemerintah Kota Bandung Melalui Kerja sama Sister City

Amerop Kemenlu, kerja sama yang dilakukan oleh pemerintah daerah dalam kerangka sister city ini pada dasar merupakan bagian dari diplomasi Indonesia, dalam hal ini akan selalu membawa kepentingan nasional Indonesia sebagai acuan kerja sama yang bertujuan untuk meningkatkan pembangunan dan kesejahteraan di daerah khususnya dan secara nasional umumnya. Pemerintah Republik Indonesia memberikan keleluasaan terhadap pemerintah kota untuk membentuk sister city, dimana hal ini tertuang ke dalam sebuah Peraturan Menteri Dalam Negeri No. 03 tahun 2008, khususnya pada pasal 5. Pasal tersebut menyebutkan lima hal yang harus diperhatikan ketika pemerintah kota hendak mengadakan kerja sama sister city/province dengan daerah lain baik internal maupun lintas Negara. Lima hal tersebut adalah:

1. Kesetaraan Status Administrasi

2. Kesamaan Karakteristik

3. Kesamaan Permasalahan

4. Upaya Saling Melengkapi; dan

5. Peningkatan Hubungan Kerja sama

Paradiplomasi Kota Bandung dalam bentuk sister city dengan Braunsweigh dan Suwon membuahkan beberapa keuntungan dan juga sekaligus peluang demi meningkatkan kesejahteraan masyarakat kota sekaligus berpartisipasi di dalam pembangunan nasional khususnya dalam mengembangkan diplomasi Indonesia.

Meskipun demikian, permasalahan utama yang menjadi pokok pembahasan adalah terkait dengan komunikasi yang belum tersampaikan dengan baik kepada masyarakat melalui sosialisasi. Beberapa program yang diadakan oleh pemerintah kota dalam hubungan sister city tersebut kebanyakan belum banyak diketahui oleh masyarakat Kota Bandung terutama masyarakat yang belum menjangkau sarana komunikasi dan informasi yang kekinian. Programprogram yang bermanfaat bagi masyarakat kerap kali banyak masyarakat Kota Bandung yang belum mengetahuinya sehingga ketercapaian tujuan yang diharapkan atas program-program yang dilaksanakan menjadi belum optimal.

Hubungan kerja sama yang terjadi di antara Kota Bandung dengan Braunsweigh dan Suwon melalui paradiplomasi yang terjadi diejawantahkan ke dalam bentuk mekanisme sister city. Dari hasil kajian dan artikel yang dilakukan, terdapat hal-hal pokok yang menjadi temuan dalam artikel di antara mekanisme sister city yang dilakukan antara Bandung-Braunschweig dengan Bandung-Suwon. Temuan tersebut dapat dilihat dalam matriks sebagai berikut.

Tabel 2. Temuan Kerja sama Sister city Bandung-Braunschweig-Suwon (Sumber: Peneliti, 2016)

\begin{tabular}{|l|lr|l|}
\hline & Braunschweig & Suwon \\
\hline Bandung & Hubungan & Kerja & Hubungan Kerja sama \\
& sama & didominasi & antara Suwon-Bandung dan \\
& Braunschweig- & Bandung & Bandung-Suwon dilakukan \\
& dibandingkan & Bandung- & secara setara \\
& Braunschweig & & Bentuk kegiatan mayoritas \\
& Bentuk kegiatan mayoritas & \\
\hline
\end{tabular}




\begin{tabular}{|l|l|l|}
\hline $\begin{array}{l}\text { berupa bantuan (aid), } \\
\text { pelatihan, dan kerja sama } \\
\text { pertukaran lainny yang } \\
\text { lazim dilakukan }\end{array}$ & $\begin{array}{l}\text { berupa pertukaran pemuda, } \\
\text { buda, bantuan (aid), } \\
\text { pelatihan, dan kerja sama } \\
\text { lainnya yang lazim } \\
\text { dilakukan } \\
\text { Braunschweig memperoleh } \\
\text { benefit berupa pengakuan } \\
\text { dan reputasi internasional } \\
\text { baik dalam kalangan negara- } \\
\text { negara berkembang yang } \\
\text { menjadi mitra kotanya memperoleh benefit } \\
\text { maupun dari negara lain. } \\
\text { berupa persahabatan tidak } \\
\text { hanya dengan pemerintah } \\
\text { kota Bandung namun juga } \\
\text { dengan masyarakat dan } \\
\text { komunitas secara langsung } \\
\text { dan juga reputasi } \\
\text { internasional dari negara } \\
\text { lain. }\end{array}$ \\
\hline
\end{tabular}

Hasil wawancara dengan Dr. Dadang Hermawan dari Sub Bagian Kerja sama Luar Negeri Kota Bandung menyatakan bahwa pola sister city Top-Down berarti merupakan pola sister city yang diinisiasi langsung oleh pemerintah sub-nasional atau sub state, dalam konteks ini adalah pemerintah Kota Bandung. Inisiasi tersebut muncul atas dasar berbagai pertimbangan langsung dari pemerintah kota misalnya seperti kebutuhan kerja sama teknologi dengan kota yang telah maju teknologinya, kerja sama dengan kota yang telah maju sistem administrasi tata pemerintahannya sehingga pemerintah kota yang bekerja sama dapat belajar dari pemerintah mitra kotanya, kerja sama dengan kota yang telah mampu memanajemen lingkungan hidup dengan baik sehingga pemerintah kota dapat belajar mengenai manajemen limbah (waste management) dan alasan lainnya semisal kesamaan geografis, kultural, maupun ekonomi. Pada pola ini Pemerintah Kota menjadi sentral bagi terjadinya aktivitas sister city sehingga kebutuhan masyarakat umum dalam aktivitas sister city tersebut muncul setelah pemerintah melakukan inisiasi terhadap hal-hal tersebut.
Hasil Wawancara dengan Dadang Hermawan (2015) menjelaskan pula mengenai tahapan paradiplomasi yang

terjadi antara kota Bandung dengan mitra kotanya yang dapat dibagi menjadi tiga tahapan utama, yakni pada proses penyusunan kesepakatan MoU, tahap implementasi, dan tahap monitoring dan evaluasi. Ketiga tahapan ini menjadi suatu penanda bahwa kegiatan paradiplomasi yang terjadi melalui sister city berlangsung dengan baik dan memiliki dampak positif bagi kemajuan kota dan masyarakat di dalamnya, dalam hal ini masyarakat kota Bandung secara khusus.

Pada saat ini, model sister city yang diterapkan di Kota Bandung masih bersifat Top Down. ${ }^{16}$ Artinya adalah bahwa segala sesuatu yang terkait dengan sister city di kota Bandung masih dipelopori dan dimulai dari Pemkot (Pemerintah Koa) Bandung. Segala bentuk permintaan kerja sama sister city yang masuk dari pemerintah negara lain menjadi dasar utama bagi pelaksanaan paradiplomasi sister city oleh pemkot Bandung. Sedangkan dasar lainnya yaitu

\footnotetext{
16 wawancara dengan narasumber Dadang Hermawan, 2015 (kasubag kerja sama luar negeri Pemkot Bandung)
} 
dari usulan pemkot Bandung itu sendiri kepada kota lain di negara sahabat yang potensial untuk melaksanakan proses kerja sama paradiplomasi dalam bentuk sister city.

Perbedaan antara model lama yang selama ini diterapkan dengan model baru yang mungkin dapat menjadi rekomendasi bagi pemerintah Kota Bandung di dalam melakukan proses paradiplomasinya dalam bentuk sister city adalah pada letak mekanismenya. Mekanisme yang dapat dilakukan pada model baru sister city Kota Bandung adalah dengan mengkombinasikan dua mekanisme berbeda yakni Top-Down dan Bottom-Up pada satu kebijakan yang sama. Hal ini memiliki arti bahwa di dalam model baru yang direkomendasikan oleh peneliti, peran serta masyarakat umum sebagai bagian dari proses paradiplomasi yang dilakukan menjadi sangat vital dan diperlukan di dalam membangun proses sister city yang dilakukan ke arah yang lebih baik.

\section{Kesimpulan}

Pelaksanaan Sister City dapat
membantu Indonesia di dalam
mewujudkan kepentingan nasionalnya
melalui diplomasi, khususnya dalam
paradiplomasi. Hal ini terwujud apabila
hubungan sister city yang dilakukan
memenuhi kaidah berikut:

1. Hubungan sister city setara seperti yang terjadi pada Bandung-Suwon. Hubungan yang setara akan menyebabkan hubungan yang terjalin akan harmonis sebab munculnya rasa saling menghargai dan menghormati antara kota yang melakukan sister city dan mitra kotanya. Dengan hubungan yang setara, tidak akan ada pihak yang merasa lebih diuntungkan daripada pihak lainnya. Hal ini dapat membantu Indonesia dalam pemerataan pembangunan di berbagai aspek khususnya ekonomi, sosial budaya dan politik yang dilakukan melalui kotakota.

2. Hubungan sister city yang lebih tinggi dimana satu pihak melakukan lebih banyak peran terhadap mitra kotanya seperti yang terjadi dan dilakukan oleh Braunschweig terhadap Kota Bandung. Hanya saja jika kepentingan nasional Indonesia ingin terwujud, maka posisinya harus dibalik, dimana Kota Bandung harus lebih melakukan banyak peran dibandingkan dengan mitra kotanya yang lain. Hal ini akan mampu untuk menguatkan reputasi internasional baik reputasi yang dimiiliki oleh kota Bandung maupun oleh Indonesia secara keseluruhan.

Pola Bottom Up dan Top Down serta gabungan di antara keduanya menjadi pola yang ideal di dalam mewujudkan proses sister city yang terjadi antara Kota Bandung dengan mitra kotanya dimana komunitas masyarakat, masyarakat umum yang awam, serta pihak swasta menjadi elemen penting disamping pemerintah Kota Bandung terlibat dalam mengisi aktivitas sister city, karena pada dasarnya sister city yang dilakukan oleh pemerintah Kota Bandung bukanlah hanya untuk kepentingan Kota Bandung itu sendiri melainkan untuk mewujudkan aspirasi dan kebutuhan dari masyarakat yang tinggal dan hidup di dalamnya.

\section{Referensi}

Buku

Bell, D. (1989). The third technological revolution and its possible socioeconomic consequences. Dissent, 36(2), 167.

Duchacek, I. 1990. Perforated Sovereignties and International Relations: Trans-Sovereign Contacts Of Subnational 
Governments (Eds). dalam Hans J. Michelmann, H.J. \&Soldatos, P. "Federalism and International Relations: The Role of Subnational Units". Oxford: Clarendon Press. p. 25

Ivo D. Duchacek,'Perforated Soveregnties: Towards a Typology of New Actors in International Relations', dan Panayotis Soldatos,'An Explanatory Framewwork for Study of Federated States as Foreign-Policy Actors', keduanya dalam Noe Cornago,'On the Normalization of Sub State Diplomacy", 2009.

Takdir Ali Mukti. 2013. Paradiplomasi kerja sama Luar Negeri Oleh Pemda di Indonesia. The Phinisi Press. Yogyakarta

\section{Jurnal}

Hepler.H (1994); "Sister Citie Program Link Culture, Business."American City and Country September: 22

Rogier van der Pluijm (2007); City Diplomacy: The Expanding Role of Cities in International Politics; Netherlands Institute of International Relations. Hal. 11

Neves, Miguel Santos. 2010.

Paradiplomacy, Knowledge Regions and the Consolidation of "Soft Power" Vol 1. Portugal: Universidade Autónoma de Lisboa.

Rosenau, J.N (1997); Along the Domestic-Foreign Frontier: Exploring Governance in a Turbulant World; dalam Fritz Ikone Nganje; Paradiplomasi: A Comparative Analyuses of the International Relation of South Africa Gauteng, North West and Western Cape Province. 2013.

Zelinsky, W. (1990); "Sister city Alliance." American Demographics 12(6)

\section{Artikel dalam Website}

Hendrini Renola Fitri dan Faisyal Rani, (2009); Implementasi Kerja sama Sister city: Studi Kasus Sister city Bandung- Braunsweigh (20002003); Jurnal Transnasional, Vol 5.
No1. Juli 2013.Diakses melalu iwww.ejournal.unri.ac.id/index.php/ JTS/article/download/1798/1769, 21/05/2013, pukul 10.20 WIB.

MKAA. 2016. The History of the Asian-African Conference. [online]. Diakses melalui <http://asianafricanmuseum.org/ en/sejarah-konferensi-asiaafrika/> [10/11/16]

MoU Sister city Kota Suwon dan Kota Bandung Pasal 1. "Kunjungan Delegasi Suwon" dalam <http://www.bandung.go.id/index.p hp? fa=berita.detail\&id=2010>, diakses pada 24 Maret 2016

The Jakarta Post. 2015. 77 countries, 34 leaders to attend Asia-Africa conference commemoration. [online]. Diakses melalui <http://www.thejakartapost.com /news/2015/04/16/77-countries34-leaders-attend-asia-africaconferencecommemoration.html> [10/11/16]

\section{Sumber Lainnya}

UU No. 32 Tahun 2004 tentang Pemerintahan Daerah

UU No.24 tahun 2000 tentang Perjanjian Internasional.

MoU Sister city Kota Suwon dan Kota Bandung

Peraturan Menteri Dalam Negeri Nomor 3 Tahun 2008 tentang Pedoman Pelaksanaan Kerja sama Pemerintah Daerah dengan Pihak Luar Negeri. 